\title{
Time Preference and Time Use: Do Smokers Exercise Less? ${ }^{*}$
}

\author{
Younghwan Song ${ }^{\dagger}$ \\ Union College
}

May 2007

\begin{abstract}
Time preference affects individuals' time-allocation decisions such as working and investments in human capital over a lifetime. It also influences individuals' choice of non-market activities on a daily basis. Individuals with higher time preference would spend more time on the non-market activities that provide rather instant gratification such as watching television and eating, whereas those with lower time preference would spend more time on the non-market activities that provide long-term returns such as exercising and taking classes. Using matched data from the Tobacco Use Supplements to the February, June and November 2003 Current Population Surveys and the 2003, 2004 and 2005 American Time Use Surveys, this paper examines how the differences in time preference, measured by smoking, affect time spent on various non-market activities in an 24hour period. Even after controlling for a host of variables, I find that current smokers, compared to never smokers, spend more time watching television and eating and drinking but less time exercising and taking classes.
\end{abstract}

JEL Classification: J2, I1

Keywords: time preference, time use, smoking

\footnotetext{
* Paper to be presented at the IZA Topic Week: Nonmarket Time in Economics, May 30-June 02, 2007, Bonn, Germany.

${ }^{\dagger}$ Correspondence: Department of Economics, Union College, Schenectady, NY 12308; E-mail:

songy@union.edu.
} 


\section{Introduction}

Time preference affects individuals’ time-allocation decisions over a lifetime such as investments in education and training (Becker 1975; Mincer 1974). Time preference also affects individuals' investments in health because health-enhancing activities involve incurring current costs for the sake of future benefits, and individuals differ in their time preference that will induce them to undertake such investments (Fuchs 1979). Given that a lifetime is the summation of the number of days during which an individual is alive, it is expected that time preference will also influence individuals' choice of activities on a daily basis, in particular non-market activities associated with investments in human capital or health capital. For example, individuals who are rather present-oriented would spend more time on the non-market activities that provide rather instant gratification such as watching television or eating and drinking. On the contrary, those who have selfcontrol would spend more time on the non-market activities that provide long-term returns such as exercising and taking classes. The focus of this paper is to examine how the differences in time preference, measured by smoking, affect time spent on various non-market activities in a day.

Since the seminal paper by Becker (1965) on the allocation of time in non-work activities, many economists have improved our understanding of various components of non-market time use, such as housework, child care, sports, sleeping, informal education, and eating (Koorman and Kapteyn 1987; Biddle and Hamermesh 1990; Fahr 2005; Hamermesh 2007). However, due to lack of data, no paper has yet incorporated the effect of time preference into the analysis of non-market time use. By matching individual data from the Tobacco Use Supplements to the February, June and November 
2003 Current Population Surveys (TUS-CPS) with the 2003, 2004 and 2005 American

Time Use Surveys (ATUS), this paper creates a large, nationally representative data set that provide detailed information on both time use and time preference, measured by smoking status of the respondent, and analyzes the effect of time preference on four nonmarket activities: watching television, eating and drinking, education, and sports.

In the discounted-utility model in economics, the concept of time preference in intertemporal choice is often measured by a single parameter - the discount rate, which should be, in determining the present value of future utility, constant over both time and different types of intertemporal choices. Although an individual's smoking status is often used as a proxy for the discount rate in intertemporal choice (Munasinghe and Sicherman 2004), some other psychological factors that are not well captured in the constant discount rate but are closely associated with time preference also explain smoking behavior. ${ }^{1}$ For example, hyperbolic discounting, habit formation, and visceral factors are all at odds with the constant discount rate but they play a prominent role in explaining smoking behavior (Frederick, Loewenstein and O’Donoghue 2002). ${ }^{2}$ Therefore, this paper imports the insights from psychology and takes the multiple-motive approach to intertemporal choice, suggested by Frederick, Loewenstein and O’Donoghue (2002). That is, smoking status is used as a proxy for individuals' time preference for immediate

\footnotetext{
${ }^{1}$ Smoking is also affected by other factors than psychology or time preference. For example, cigarette prices, health scares, and advertising also affect the demand for cigarettes (Cameron 1998). To the extent that the association between smoking and time preference is weakened due to these other factors, the empirical estimates of the effect of time preference on time use will be underestimated.

${ }^{2}$ Hyperbolic discounting means that the discount rate over longer time horizons is lower than the discount rate over shorter time horizons. It explains why preference between two delayed rewards can reverse in favor of the more imminent reward as the time to both rewards diminishes. For example, some one may prefer \$150 in 11 years over \$100 in 10 years, but also prefer \$100 now over \$150 in a year from now. Habit formations means that the utility from current consumption can be affected by the level of past consumption. Thus it often induces a preference for an increasing consumption profile. By increasing the attractiveness of certain goods or activities, visceral factors — such as hunger, sexual desire, physical pains, and cravings — can give rise to behaviors that look extremely impatient or even impulsive.
} 
utility over delayed utility, as will be discussed in Section 2, because of, but not limited to, discount rates, impulsivity, and planning horizon. Individuals who are present (future)-oriented due to these various factors will be labeled as having higher (lower) time preference.

Another contribution of this paper is about the nonresponse in the ATUS. Through the merging of the ATUS and the TUS-CPS, this paper shows that the survey response rate in the ATUS also varies by smoking status of the respondent. Given the recent interest regarding the quality of the ATUS, ${ }^{3}$ this is an interesting result that can potentially improve the process of data collection and analysis of both TUS-CPS and ATUS.

The remainder of the paper is organized as follows. In Section 2, I summarize the relationship between smoking status and time preference in the literature. In Section 3, I discuss the effect of time preference on time use. Section 4 describes the data and the matching process. In Section 5, I present the empirical results and discuss the findings. Finally, Section 6 provides concluding remarks.

\section{Smoking and Time Preference}

The relationship between smoking and time preference has been well documented in both economics and psychology literature. The empirical evidence in economics literature is often based on large data sets. Fuchs (1982), using a survey of 508 community members aged 25 to 64, first showed that cigarette smoking does increase with discount rates, calculated from a series of monetary time-preference questions such as "Would you

\footnotetext{
${ }^{3}$ For the nonresponse in the ATUS, see Abraham, Maitland, and Bianchi (2006) and Abraham, Helms, and Presser (2007).
} 
choose $\$ 1,500$ now or $\$ 4,000$ in five years?” However, the magnitude of the effect of the discount rate on cigarette smoking was quite small.

In an effort to analyze the relationship between smoking status, and time and risk preference, and valuation of health, Khwaja, Sloan, and Salm (2006) used large nationally representative panel data of the elderly drawn from the first six waves (19922002) of the Health and Retirement Study. They found, first of all, that current smokers are more present-oriented than never smokers. To be specific, current smokers have shorter time horizons in financial planning than never smokers, while the time horizon for former smokers does not differ from that for never smokers. Assuming that the length of the planning horizon captures not only longevity expectations but also other factors such as planning ability or more general skills of self-control (Ameriks, Caplin, and Leahy 2003), current smokers seem to have less self-control.

Khwaja, Sloan, and Salm (2006) also found that current smokers are more pessimistic about future macroeconomic events, such as depression or double-digit inflation, than never smokers, while there are no differences in expectations between former and never smokers. When it comes to relative risk tolerance, calculated using responses to a gamble based on lifetime earnings, they found that both current and former smokers are more risk tolerant than never smokers. Their results from fixed-effect estimations suggested that being more present-oriented and risk tolerant is not caused by smoking, but represents time-invariant innate characteristics. Finally, in health valuation measured by willingness to pay for additional treatment to be in perfect health, they found no difference by smoking status. 
In contrast, Khwaja, Silverman, and Sloan (2006), using a sample of adults aged 50-70 drawn from the Survey on Smoking (SOS) that was collected for their own research, concluded that it is inappropriate to proxy time preference with measures of smoking behavior. This conclusion is based on their finding that subjective rates of time discount, revealed through either intertemporal financial or health tradeoff questions in the SOS, are unrelated to differences in smoking behavior. Yet, they still found that current smokers have shorter financial planning horizons and tend to be more impulsive than never smokers. ${ }^{4}$ Former smokers are not different from never smokers in planning horizons but are more impulsive than never smokers. On the whole, they concluded that smoking, rather than simply being a sign of higher time discount rates, may be an indicator of greater problems of self-control that emerge through other channels.

Compared to those in economics literature, the empirical results in psychology are based on relatively small samples in controlled experiment settings. Nevertheless, they also resoundingly provide strong evidence that smoking status is a strong indicator of individuals’ time preference. Using a small, experimental sample ( $n=66)$, Bickel, Odum, and Madden (1999) found evidence for hyperbolic discounting: the hyperbolic function provides a better fit to data in models of delay discounting than the exponential function. They also found that current smokers discount the value of delayed money to a greater extent than do never smokers or former smokers, but never smokers and former smokers do not differ in their discounting of delayed outcomes. For such similarities in discounting between never smokers and former smokers, they suggested two

\footnotetext{
${ }^{4}$ Impulsivity was measured in the telephone interview of the SOS by using the answers to a series of 14 statements, such as "I make hasty decisions," "I do not control my temper," and "I act on impulse." They used impulsivity as "a measure of an individual's ability to set goals and to exercise self-control" (Kawaja, Silverman, and Sloan 2006, p.20).
} 
explanations. First, chronic cigarette smoking could produce steeper discounting, but upon cessation this effect may be reversible and the degree of discounting may decrease. Second, it could be due to a selection bias: perhaps only smokers with a relatively low degree of discounting are able to successfully quit smoking and thereby become former smokers. ${ }^{5}$ They cautiously, due to their small sample size, supported the selection bias explanation.

Mitchell (1999) also confirmed that smokers are more impulsive than never smokers. Using a sample of twenty regular smokers and twenty never smokers, she found that smokers choose small, immediate money over large, delayed money more frequently on behavioral choice tasks.

Finally, Odum, Madden, and Bickel (2002) found that current cigarette smokers discount health outcomes to a greater extent than do never smokers, which is different from the findings in Khwaja, Silverman, and Sloan (2006). Discounting by former smokers is between that of current smokers and never smokers, though not generally statistically different from either. Both current and former smokers discount health losses to a greater extent than health gains (the sign effect), but never smokers do not discount gains and losses differently. ${ }^{6}$

In summation, both economics and psychology literature on time preference and smoking suggests that measures of smoking behavior are not a simple proxy for the constant discount rate, but still, based on the multiple-motive to intertemporal choice, a strong indicator of individuals' time preference. Current smokers have higher time

\footnotetext{
${ }^{5}$ Bretteville-Jensen (1999) provides the same set of explanations for the differences in discount rates between active and former users of hard narcotic substances. Also see Bickel and Johnson (2003). ${ }^{6}$ See Chapman (2003) for an overview of the differences and similarities between health and money discounting.
} 
preference, that is, stronger preference for immediate utility over delayed utility than never smokers. Former smokers seem to be between current smokers and never smokers in their time preference.

\section{Time Preference and Time Use}

Given that a lifetime is the summation of the number of days during which an individual is alive, it is expected that time preference will influence individuals' choice of activities on a daily basis, in particular non-market activities associated with investments in human capital or health capital. This paper analyzes the effect of individuals' time preference, measured by smoking status, on time spent on the following activities: watching television, eating and drinking, education, and sports.

Individuals who are rather present-oriented would spend more time on the nonmarket activities that provide rather instant gratification such as watching television, even though time spent watching television is positively associated with significantly elevated risk of future health problems such as obesity and diabetes (Hu et al. 2001, 2003). Eating and drinking is another activity that provides instant gratification. ${ }^{7}$ Individuals with higher time preference may spend more time eating and drinking. In fact, in a review of cross-sectional studies, Perkins (1992) found that smokers tend to eat slightly more than nonsmokers. However, it also is possible that individuals with higher time preference may spend the same amount of time eating and drinking as those with lower time preference, but simply consume different types of food than what people with lower time preference consume. Indeed, Huston and Finke (2003) showed that individuals with higher discount rates, measured by a set of variables that include smoking and education,

\footnotetext{
${ }^{7}$ Thus the increase in time preference can contribute to obesity (Smith, Bogin, and Bishai 2005).
} 
tend to have a less healthy diet. Through a meta-analysis of the publications on nutrition, Dallongeville et al. (1998) also found that smokers have unhealthy patterns of nutrient intake.

Those who have self-control would spend more time on the non-market activities that provide long-term returns such as sports and education. Using data drawn from the National Medical Expenditure Survey, Hersch (1996) found that smokers are less likely to use seat belt, brush or floss teeth, and do physical exercise. Levine, Gustafson and Velenchik (1997), using data drawn from the National Longitudinal Survey of Youth, showed that smokers have substantially less education than nonsmokers. Recently, using detailed time use data for Germany, Fahr (2005) found a positive correlation between the level of schooling and time investments in informal education ${ }^{8}$, independent of wage effect, and concluded that it reflects a taste effect, which includes time preference.

One competing hypothesis that can also explain the suggested differences in time spent on various activities by smoking status is health. Smokers, compared to never smokers, spend more time watching television but less time exercising and taking classes simply because they are likely to be less healthy, and health could be a determining factor in these time-use patterns. Because information regarding the health status of the respondents is not available in the data used in this paper, I cannot directly control for the differences in health status. ${ }^{9}$ Nevertheless, as a way to gauge the effect of unobserved health status, I analyze the effect of smoking status on working, under the presumption that unhealthy people are likely to spend less time working than healthy people, but given

\footnotetext{
${ }^{8}$ Fahr (2005, p. 77) defined informal education as all educational activities that take place after work-time and serve the current job only to a minor part. In another definition, she also included all sorts of (nonfiction) reading activities in informal education.

${ }^{9}$ From October 2005 to December 2006, the ATUS includes the Food \& Eating Module which collects information on subjective health status, height, and weight. This data is not available yet.
} 
the constraints on work schedule in many jobs, working time is less likely to be affected by time preference.

\section{Data}

\subsection{Matching of ATUS and TUS-CPS}

In order to measure the effect of time preference on time use, this paper uses matched data from the 2003, 2004 and 2005 American Time Use Surveys and the Tobacco Use Supplements to the February, June and November 2003 Current Population Surveys.

The ATUS is a time diary study that collects a detailed account of respondents' activities on a preassigned day of the week (the diary day), starting at 4 a.m. on the day before the interview and ending at 4 a.m. on the day of the interview. The diary days of the ATUS are inclusive of all days in a year-weekdays, weekends and holidays, except Thanksgiving Day and Christmas Day. For each activity, respondents also report how long the activity lasted and where the activity took place. The ATUS also collects demographic information of each household member, such as sex and age. The ATUS sample is drawn from households that have completed their final interview with the Current Population Survey (CPS). The CPS is a monthly survey of almost 60,000 households and is the primary source of information on the labor force characteristics of the U.S. population. Two to five months after the last CPS interview, one individual aged 15 or older from each selected household is randomly chosen to participate in the ATUS and this designated person is interviewed to report time use about the diary day.

Although the ATUS collected detailed information on time use on the diary day, the time use information in the ATUS is not adequate to tell whether a respondent is a 
smoker or not. First, activities with very short duration, such as smoking a cigarette, which takes less than five minutes, are less likely to be reported than other activities with longer duration in the ATUS. Second and more importantly, smoking is often done simultaneously with other activities, such as watching TV, driving a car, reading, and drinking. Yet, except for secondary childcare, activities done simultaneously with primary activities were not collected in the ATUS. Hence, the amount of time spent on smoking is to a large extent underreported in the ATUS.

Therefore, in this paper the data on the respondent's smoking status come from the February, June and November 2003 TUS-CPS. The TUS-CPS has been collected as a supplement to the CPS in February, June and November 2003 CPS and is a key source of national level data on smoking and other tobacco use in the U.S. household population ages 15 years and older. ${ }^{10}$ In the TUS-CPS, respondents were asked a) Have you smoked at least 100 cigarettes in your entire life? and b) Do you now smoke cigarettes every day, some days, or not at all? Based on the responses to these questions, I have classified individuals into three groups by smoking status: never smokers, current smokers, and former smokers. Never smokers are those who have never smoked at least 100 cigarettes in their entire life; current smokers are those who now smoke cigarettes every day or some days; and former smokers are those who had smoked at least 100 cigarettes, but who were no longer smoking at the time of the interview. In order for the smoking status to be a valid proxy for an individual's time preference, the respondent should be old enough to be over the legal smoking age. Three states-Alabama, Alaska and Utah-had the legal smoking age set at 19 and all other states had the legal smoking age of at 18 in

\footnotetext{
${ }^{10}$ For descriptive findings from the February, June and November 2003 TUS-CPS, see Hartman et al. (2006). The TUS-CPS was also administered in 1992-93, 1995-96, 1998-99, 2000, and 2001-02.
} 
2003 (Ahmad 2005). Therefore, I use individuals who are over the age of 19 as of the TUS-CPS interview in my analysis.

By utilizing the 4-8-4 sampling rotation scheme in the CPS, one can match observations from the February, June and November 2003 TUS-CPS to the 2003, 2004 and 2005 ATUS. Each month there are eight rotation groups in the CPS. A new rotation group of households enters the survey every month and is interviewed for four consecutive months, temporarily out for eight consecutive months, and then reinterviewed for four consecutive months before they are finally dropped from the CPS. And two to five months after the last CPS interview, some of these households are eligible for the ATUS interview.

Table 1 shows when each rotation group of households in the TUS-CPS completed the final interview in the CPS and became eligible for the ATUS interview. For example, a group of households that was in its seventh month of interview (Month in Sample, or MIS, 7 in CPS parlance) in the February 2003 TUS-CPS finished its eighth month of interview in the CPS in March 2003 and became eligible for the ATUS interview in May through August 2003. Excluding the two rotation groups of households in the February 2003 CPS —-those in MIS 4 and 8-that were interviewed for the basic CPS but not for the Tobacco Use Supplement, there are 22 non-overlapping rotation groups of households from the February, June and November 2003 TUS-CPS and they can provide information on smoking status for the ATUS respondents who were interviewed between May 2003 and July 2005.

Following the guidelines in Bureau of Labor Statistics (2006), I first linked observations from the February, June and November 2003 TUS-CPS and the 2003, 2004 
and 2005 ATUS by using a set of household and individual identification variables then only kept the observations that have the same values for sex and race, and acceptable ranges of age difference between the two surveys. ${ }^{11}$

Table 2 shows the number of individuals that are matched between the 2003, 2004 and 2005 ATUS and the February, June and November 2003 TUS-CPS. The size of sample drawn for interviews in the ATUS was reduced from 38,938 cases in the 2003 ATUS to 27,004 and 24,977 cases in the 2004 and 2005 ATUS, respectively. Last column of Table 2 shows that using a set of household and individual identification variables, among the sample of 90,919 individuals selected for the ATUS sample after leaving the CPS, 37,017 individuals over the age of 19 are successfully merged to the TUS-CPS sample. And 35,897 observations remained after excluding cases with nonmatching sex, race, and age between the two surveys. Among these individuals, the number of respondents who completed the ATUS interviews was 20,430. ${ }^{12}$

Given the recent interest in the quality of the ATUS (Abraham, Maitland, and Bianchi 2006; Abraham, Helms, and Presser 2007), it is an interesting analysis to examine the response rate to the ATUS by smoking status. According to Abraham, Maitland, and Bianchi (2006), people who are weakly integrated into their communities, such as renters, are less likely to respond to the ATUS. They also showed that the official ATUS final weight reasonably adjusts estimates for nonresponse bias. Another reason why nonresponse analysis is important is because different response rates may

\footnotetext{
11 The set of household and individual identification variables used in matching are HRHHID, PULINENO, HUHHNUM, HRSERSUF, and HRSAMPLE. For acceptable ranges of age difference between the 2003 TUS-CPS and the ATUS, I used 0-2 years for the 2003 ATUS, 0-3 years for the 2004 ATUS, 1-3 years for the 2005 ATUS. It is based on the fact that in Table 1 the numbers of months between the CPS-TUS and ATUS range 2-8 months for the 2003 ATUS, 2-20 months for the 2004 ATUS, and 1420 months for the 2005 ATUS.

${ }^{12}$ The total number of completed interviews in the ATUS was 20,720 cases in 2003, but it was reduced, as a result of the reduction in sample size, to 13,973 and 13,038 cases in 2004 and 2005, respectively.
} 
cause bias in the estimates of time use. For example, by matching the CPS Volunteering Supplement to the ATUS, Abraham, Helms, and Presser (2007) found that those who said in the CPS Volunteering Supplement that they had volunteered have a higher response rate in the ATUS than those who said they had not volunteered. As a result, they found that the estimates of volunteering in the ATUS are too high.

The response rate to the ATUS by smoking status reported in Table 3 indeed indicates that current smokers are about 2 percentage points less likely to respond to the ATUS than never smokers, which is consistent with the findings in the literature on survey nonresponse (Oakes, Friedman, and Seltzer . 1973; Seltzer, Bosse, and Garvey 1975; Gray et al. 1996; Cunradi et al. 2005). One explanation for why current smokers are less likely to respond is that they are more likely than never smokers to develop health problems that would decrease their ability to respond to the subsequent survey. Another explanation is that higher time preference of current smokers makes them, somehow, less willing to participate in the subsequent survey.

Surprisingly, among the three groups in Table 3, former smokers are more likely to respond to the ATUS than never smokers and thus have the highest response rate of 62.5 percent. In the literature on survey response, Oakes, Friedman, and Seltzer (1973) also found that former smokers are more cooperative in responding to mail survey than either current smokers or never smokers. If one may extend the two explanations provided by Bickel, Odum, and Madden (1999) regarding the similarities in discounting between never smokers and former smokers - reversibility and selection, the higher response rate by former smokers than any other group seems to support the selection explanation. If cessation could reverse the increase in time preference due to smoking 
only to the level of never smokers, the response rate among former smokers cannot be higher than that among never smokers. It appears that smokers who are able to successfully quit smoking and thereby become former smokers are different even from never smokers in their behavior. Yet, the precise reason for the higher response rate among former smokers definitely merits further research.

As a result of the higher response rate among former smokers, Table 4 shows that the proportion of former smokers is higher among the ATUS respondents than among the ATUS nonrespondents, whereas the proportions of never smokers and current smokers are significantly lower among the ATUS respondents than among the ATUS nonrespondents.

Table 5 reports the marginal effects derived from the multivariate probit regression with the ATUS response as the dependent variable. After controlling for a set of demographic and socioeconomic variables, similar to those used in Abraham, Maitland and Bianchi (2006), ${ }^{13}$ column 1 of Table 5 shows that former smokers are still about 5 percentage points more likely to participate in the ATUS interview than never smokers, while now there is no significant difference in response rates between current smokers and never smokers. In a separate analysis by sex reported in columns 2 and 3 of Table 5 , these results do not substantially change, except that in column 3, current smokers are about 2 percentage points more likely to respond to the ATUS survey than never smokers among women.

\footnotetext{
${ }^{13}$ The independent variables are dummies for current smokers and former smokers (the reference group is never smokers); female dummy; age and its square; three dummies for race/ethnicity; three education dummies; an employment dummy; number of children living in the household; four family income dummies; a dummy for no telephone in the household; renter dummy; two TUS-CPS month dummies, a SMSA dummy; and three region dummies.
} 
Overall, the results in Tables 3, 4, and 5 illustrate that former smokers are overrepresented in the sample of ATUS respondents.

\subsection{Descriptive Statistics}

Table A1 in the appendix lists how each time-use category has been created from the ATUS activity classification codes. In addition to the four activities of interestwatching television, eating and drinking, education, and sports, I have created working time in order to check if the estimated effects of time preference, measured by smoking status, on time-use are simply reflecting the difference in health status by smoking status. Finally, I have also created smoking time in order to show the underreporting of time spent smoking in the ATUS.

Table 6 presents the proportion of respondents who spent non-zero time on smoking in the ATUS. ${ }^{14}$ There are three things noteworthy in Table 6. First, the distribution of respondents reported non-zero smoking time in Table 6 is consistent with the smoking status reported in the TUS-CPS. Current smokers have the highest proportion reported non-zero smoking time, formers smokers the second highest, and never smokers the lowest. Second, as describe in Section 4.1, the level of underreporting of time spent smoking in the ATUS is substantial. Less than 10 percent of current smokers reported non-zero smoking time in the ATUS. This underreporting clearly demonstrates the need for using the TUS-CPS for smoking status. And third, though the magnitudes are small, there seems to be changes in smoking status between the TUS-CPS and the ATUS. About 0.2 percent of never smokers and about 0.6 percent of former

\footnotetext{
${ }^{14}$ All reported results are weighted using the ATUS final weights. Following the ATUS User's Guide (Bureau of Labor Statistics 2007, pp. 24-25), I used TU04FWGT for the 2003 ATUS and TUFINLWGT for the 2004 and 2005 ATUS.
} 
smokers in the TUS-CPS reported non-zero smoking time in the ATUS. These changes could be due to the difference in the notion of smoking between the TUS-CPS and the ATUS. In the TUS-CPS smoking explicitly means smoking a cigarette, whereas in the ATUS smoking time includes not only time spent on smoking cigarettes but also time spent on other various activities related to tobacco and drug use, such as smoking a cigar/pipe, chewing tobacco, smoking marijuana, smoking pot/weed, and using recreational drugs. Thus, it certainly is possible that never smokers or former smokers in the TUS-CPS may report non-zero smoking time in the ATUS. Also the fact that there are 2-20 months gap between the two surveys might be another reason for the changes in smoking status between the two surveys. If respondents have indeed changed their smoking status between the surveys, the estimates of smoking status is subject to measurement error and have a downward bias.

Table 7 presents the average minutes spent in five time-use categories by sex and by smoking status. The first row of Table 7 shows that both current smokers and former smokers spend more time watching television than never smokers, regardless of sex. Among men, never smokers spend on average about 149 minutes per day watching television; current smokers spend on average about 50 more minutes per day watching television than never smokers; and former smokers spend on average about 33 more minutes per day watching television than never smokers. A comparison by sex shows that on average women spend less time watching television than men for each and every smoking status. Among women, never smokers spend on average about 138 minutes per day watching television; current smokers spend on average about 25 more minutes per day watching television than never smokers; and former smokers spend on average about 
16 more minutes per day watching television than never smokers. This pattern is consistent with the notion that individuals who are rather present-oriented would spend more time on the non-market activities that provide rather instant gratification such as watching television.

When it comes to time spent on other activities in Table 7, the differences by smoking status are not as consistent as those observed in time spent watching television. Among men, former smokers spend on average 10 more minutes on eating and drinking than never smokers, but among women, current smokers spend on average 5 fewer minutes on eating and drinking than never smokers. Among men, both current smokers and former smokers spend less time on education than never smokers; among women, however, only former smokers spend significantly less time on education than never smokers. Time spent on sports activities do not vary significantly by smoking status among men, but current smokers spend significantly less time on sports than never smokers among women.

Table 7 also shows time spent on working by sex and by smoking status. Among men, both current smokers and former smokers spend less time working than never smokers; among women, there is no statistically significant difference in working time by smoking status. Overall, the time-use pattern observed in Table 7 is consistent with the time preference explanation. But one cannot rule out the possibility that the observed relationship is due to the difference in health status by smoking status.

Table 8 reports further descriptive statistics for the sample by sex and by smoking status. There are substantial differences in the demographic and socioeconomic characteristics by smoking status. First of all, former smokers are about 10-12 years 
older than either never smokers or current smokers, regardless of sex. There are also more whites among current smokers and former smokers than among never smokers, regardless of sex. The percentage distributions among the four educational categories indicate that current smokers are less educated than other two groups and never smokers are better educated than other two groups, regardless of sex. Among men, both current smokers and former smokers are significantly less likely to be employed than never smokers. Current smokers are less likely to be married than never smokers but former smokers are more likely to be married than never smokers, regardless of sex. ${ }^{15}$ Finally, both current smokers and former smokers have fewer children living in the household than never smokers.

\section{Results}

In order to estimate the effect of time preference, proxied by smoking status, on the five categories of time use, this paper employs both Ordinary Least Squares (OLS) and Tobit estimations. For activities that include a substantial number of observations censored at zero, it is necessary to employ the Tobit estimation procedure, assuming that the error term is normally distributed, to get unbiased estimates. The dependent variables are the amount of time, measured in minutes, spent on each activity in a day. The independent variables include dummies for current smokers and former smokers (the reference group is never smokers); age and its square; three dummies for race/ethnicity; three education dummies; an employment dummy; number of children living in the household; four family income dummies; dummies for Saturdays, Sundays, and holidays; eleven month dummies; two year dummies; a SMSA dummy; and three region dummies.

\footnotetext{
${ }^{15}$ This pattern in marital status by smoking status is also consistent with the findings in Broms et al. (2004).
} 
Table 9 presents the results of the OLS estimation for men. Column 1 of Table 9 indicates that current smokers spend about 26 more minutes per day watching television than never smokers, even after controlling for other variables. The difference in time spent watching television between former smokers and current smokers is very small and statistically insignificant. Other significant control variables have reasonable signs and magnitudes. Time spent watching television increases with age. Thus, the significant difference observed in Table 7 seems to be due to the fact that former smokers are about 12 years older than never smokers. More educated men spend less time watching television. So do employed men, compared with those not working. Finally, time spent on watching television decreases on average by about 9 minutes per one additional child in the household.

Column 2 of Table 9 shows that both current smokers and former smokers spend about 4 more minutes per day eating and drinking than never smokers, even after controlling for other variables. Column 3 of Table 9 indicates that both current smokers and former smokers spend about 5 fewer minutes per day on education than never smokers, even after controlling for other variables. So far the results in Columns 1 through 3 of Table 9 are consistent with the notion that smokers, due to their higher time preference, spend more time on activities that provide rather instant gratification, such as watching television and eating and drinking, but spend less time on activities that provide long-term returns, such as education.

The results in column 4 of Table 9, however, are inconsistent with this idea regarding the relationship between time preference and time use. There is no significant 
difference between current smokers and former smokers in time spent on sports activities and former smokers spend about 4 more minutes on exercising than never smokers.

In order to see if the observed effects of smoking on time use in columns 1 and 3 are due to the differences in health status by smoking status, ${ }^{16}$ column 5 of Table 9 reports the estimation results using time spent on working as the dependent variable. No significant difference between current smokers and never smokers in time spent on working in column 5 supports the interpretation that the observed effects of smoking on time use in columns 1 and 3 are due to the differences in time preference by smoking status. The coefficient on the former smoker dummy is significant and negative and thus suggests that the observed effects of smoking on time use in column 3 could be due to the differences in health status by smoking status.

The OLS estimation results reported in Table 10 for women have fewer significant coefficients on the two smoking dummy variables but the overall pattern is consistent with the notion of different time use due to different time preference. In column 1 of Table 10, both current smokers and former smokers spend more time watching television than never smokers among women. In column 2, time spent on eating does not differ by smoking status, but in column 3 current smokers spend less time on education than never smokers. Different from the results for men, in column 4 of Table 10 women who currently smoke spend about 4 fewer minutes in sports activities than comparable women who have never smoked. Finally, in column 5 of Table 10 time spent on working does not significantly vary by smoking status among women.

\footnotetext{
${ }^{16}$ Column 2 is excluded because differences in health status are not likely to increase time spent on eating and drinking more for smokers than never smokers.
} 
To address the issue of censoring at zero, Tables 11 and 12 reports the marginal effects of the Tobit estimation results for men and women, respectively. ${ }^{17}$ The proportion of respondents with zero time use varies from about 5 percent for eating and drinking time to about 97 percent for education time in Tables 11 and 12. The marginal effects of the Tobit estimation for men in columns 1 through 4 in Table 11 are more supportive of the notion of different time use due to different time preference. In particular, column 4 of Table 11, different from the results in column 4 of Table 9, shows that current smokers spend about 5 fewer minutes on sports activities than never smokers among men. Due to a large number of observations being censored at zero, the OLS estimate reported in column 4 of Table 9 seems to be biased. In columns 1 through 3 of Table 11, the results of the marginal effects of the Tobit estimation still confirm the conclusion from the OLS estimation results in Table 9. Current smokers spend more time watching television and eating but less time in education than never smokers. The pattern for former smokers in columns 1 through 4 of Table 11 is also similar to that in Table 9, except that now there is no difference in time spent on exercising between former smokers and never smokers in column 4 of Table 11. Finally, in column 5 of Table 11, there is still no significant difference between current smokers and never smokers in time spent on working, while the coefficient on the former smoker dummy is significant and negative. Thus, there is no evidence that the observed difference in time use for current smokers is due to the difference in health status. The marginal effects of the Tobit estimation results in Table 12 for women are similar to the OLS estimation results reported in Table 10.

\footnotetext{
${ }^{17}$ The marginal effects of the Tobit estimation are for the unconditional expected value of the dependent variable.
} 
In summation, the empirical results, in particular for men, are consistent with the notion that individuals with higher time preference would spend more time on the nonmarket activities that provide rather instant gratification such as watching television and eating and drinking, whereas those with lower time preference would spend more time on the non-market activities that provide long-term returns such as exercising and taking classes.

\section{Conclusion}

Using matched data from the Tobacco Use Supplements to the February, June and November 2003 Current Population Surveys and the 2003, 2004 and 2005 American Time Use Surveys, this paper showed how the differences in time preference, measured by smoking status, affect time spent on various non-market activities in an 24-hour period. Even after controlling for a host of variables, I have found that among men current smokers, compared to never smokers, spend more time watching television and eating and drinking but less time exercising and taking classes. The estimates for women also provide similar, though weak, results.

Even though it has been shown that former smokers are more likely to respond to the ATUS than either never smokers or current smokers, the issue of nonresponse bias has not been fully addressed in interpreting the effect of smoking status on time use. Because the focus of the paper is not estimating time spent on smoking in the ATUS but measuring the effect of time preference, measured by smoking status, the bias due to different response rate might be insignificant. 
This paper has analyzed only the total amount time spent on each activity by smoking status. Yet the ATUS also provides detailed information regarding the timing of each activity, and time preference is likely to affect the timing of different activities in a day. Therefore, an analysis of the timing of different activities by smoking status would be an interesting research agenda.

When the Food \& Eating Module to the ATUS becomes available, it would be also interesting to examine how the different pattern in time use coupled with smoking status would affect health outcomes. Finally, another interesting research topic would be to examine whether the TUS-CPS estimates are underestimating the prevalence of smoking due to nonresponse bias by smoking status. 


\section{References}

Abraham, Katharine G., Aaron Maitland, and Suzanne M. Bianchi. 2006. "Nonresponse in the American Time Use Survey: Who is Missing from the Data and How Much Does It Matter?” Public Opinion Quarterly 70 (5), 676-703.

Abraham, Katharine G., Sara Helms, and Stanley Presser. 2007. "The Effects of Survey Nonresponse on Inferences about Volunteer Work in the United States,” Unpublished manuscript, University of Maryland.

Ahmad, Sajjad. 2005. “The Cost-Effectiveness of Raising the Legal Smoking Age in California,” Medical Decision Making 25 (3), 330-340.

Ameriks, John, Andrew Caplin, and John Leahy. 2003. "Wealth Accumulation and the Propensity to Plan,” Quarterly Journal of Economics 118 (3), 1007-1047.

Becker, Gary S. 1965. “A Theory of the Allocation of Time,” Economic Journal 75 (299), 493-517.

Press.

1975. Human Capital, 3rd Edition, Chicago, IL: University of Chicago

Bickel, Warren K., Amy L. Odum, and Gregory J. Madden. 1999. "Impulsivity and Cigarette Smoking: Delay Discounting in Current, Never, and Ex-smokers,” Psychopharmacology 146, 447-454.

Bickel, Warren K. and Matthew W. Johnson. 2003. "Delay Discounting: A Fundamental Behavioral Process of Drug Dependence,” In Time and Decision: Economic and Psychological Perspectives on Intertemporal Choice, edited by George Loewenstein, Daniel Read, and Roy Baumeister. New York: Russell Sage Foundation.

Biddle, Jeff E. and Daniel S. Hamermesh. 1990. "Sleep and the Allocation of Time," Journal of Political Economy 98 (5), 922-943.

Bretteville-Jensen, A.L. 1999. “Addiction and Discounting,” Journal of Health Economics 18 (4), 393-407.

Broms, Ulla, Karri Silventoinen, Eero Lahelma, Markku Koskenvuo, and Jaakko Kaprio. 2004. "Smoking Cessation by Socioeconomic Status and Marital Status: The Contribution of Smoking Behavior and Family Background," Nicotine \& Tobacco Research 6 (3), 447-455.

Cameron, Sam. 1998. "Estimation of the Demand for Cigarettes: A Review of the Literature,” Economic Issues 3 (2), 51-71.

Chapman, Gretchen B. 2003. “Time Discounting of Health Outcomes,” In Time and Decision: Economic and Psychological Perspectives on Intertemporal Choice, edited by George Loewenstein, Daniel Read, and Roy Baumeister. New York: Russell Sage Foundation.

Cunradi, Carol B., Roland Moore, Moira Killoran, and Genevieve Ames. 2005. "Survey Nonresponse Bias Among Young Adults: The Role of Alcohol, Tobacco, and Drugs,” Substance Use \& Misuse 40 (2), 171-185. 
Dallongeville, Jean, Nadine Marecaux, Jean-Charles Fruchart, and Philippe Amouyel. 1998. "Cigarette Smoking Is Associated with Unhealthy Patterns of Nutrient Intake: A Meta-analysis,” Journal of Nutrition 128 (9), 1450-1457.

Fahr, Rene. 2005. "Loafing or Learning? The Demand for Informal Education,” European Economic Review 49, 75-98.

Frederick, Shane, George Loewenstein, and Ted O’Donoghue. 2002. “Time Discounting and Time Preference: A Critical Review,” Journal of Economic Literature 40, 351-401.

Fuchs, Victor R. 1979. “Economics, Health, and Post-Industrial Society,” Millbank Memorial Fund Quarterly 57 (2), 153-182. . 1982. “Time Preference and Health: An Exploratory Study,” In V.R. Fuchs (Ed.) Economic Aspects of Health, Chicago, IL: University of Chicago Press, 93-120.

Gray, Rebecca, Pamela Campanelli, Kavita Deepchand, and Patricia Prescott-Clarke. 1996. "Exploring Survey Non-response: the Effect of Attrition on a Follow-up of the 1984-85 Health and Life Style Survey,” Statistician 45 (2), 163-183.

Hamermseh, Daniel S. 2007. “Time to Eat: Household Production Under Increasing Income Inequality,” American Journal of Agricultural Economics, forthcoming.

Hartman, Anne M., Gordon Willis, William W. Davis, Danell Watkins, Deirdre Lawrence, James T. Gibson, Michael Coffey. 2006. "The 2003 Tobacco Use Special Cessation Supplement to the Current Population Survey (TUSCS-CPS): Representative Survey Findings,” available on the Web at http://riskfactor.cancer.gov/studies/tus-cps/results/data03/cps_results03.pdf

Hersch, Joni. 1996. “Smoking, Seat Belts, and Other Risky Consumer Decisions: Differences by Gender and Race,” Managerial and Decision Economics 17, 471481.

Hu, Frank B., Michael F. Leitzmann, Meir J. Stampfer, Graham A. Colditz, Walter C. Willett, and Eric B. Rimm. 2001. "Physical Activity and Television Watching in Realtion to Risk for Type 2 Diabetes Mellitus in Men,” Archives of Internal Medicine 161, 1542-1548.

Hu, Frank B., Tricia Y. Li, Graham A. Colditz, Walter C. Willett, and JoAnn E. Manson. 2003. "Television Watching and Other Sedentary Behaviors in Relations to Risk of Obesity and Type 2 Diabetes Mellitus in Women," Journal of the American Medical Association 289 (14), 1785-1791.

Huston, Sandra J. and Michael S. Finke. 2003. "Diet Choice and the Role of Time Preference,” Journal of Consumer Affairs 37 (1), 143-160.

Khwaja, Ahmed, Dan Silverman, and Frank Sloan. 2006. “Time Preference, Time Discounting, and Smoking Decision,” NBER Working Paper \#12615.

Khwaja, Ahmed, Frank Sloan, and Martin Salm. 2006. "Evidence on Preferences and Subjective Beliefs of Risk Takers: The Case of Smokers,” International Journal of Industrial Organization 24, 667-682. 
Koorman, Peter, and Arie Kapteyn. 1987. "A Disaggregate Analysis of the Allocation of Time within the Household,” Journal of Political Economy 95 (2), 223-249.

Levine, Phillp B., Tara A. Gustafson, and Ann D. Velenchik. 1997. "More Bad News for Smokers? The Effects of Cigarette Smoking on Wages," Industrial and Labor Relations Review 50 (3), 493-509.

Mincer, Jacob. 1974. Schooling, Experience, and Earnings. New York, NY: National Bureau of Economic Research.

Mitchell, Suzanne H. 1999. "Measures of Impulsivity in Cigarette Smokers and Nonsmokers," Psychopharmacology 146: 455-464.

Munasinghe, Lalith, and Nachum Sicherman. 2005. "Why Do Dancers Smoke? Smoking, Time Preference, and Wage Dynamics,” Barnard College, mimeo.

Oakes, Thomas W., Gary D. Frideman, and Carl C. Seltzer. 1973. "Mail Survey Response by Health Status of Smokers, Nonsmokers, and Ex-smokers," American Journal of Epidemiology 98 (1), 50-55.

Odum, Amy L., Gregory J. Madden, and Warren K. Bickel. 2002. "Discounting of Delayed Health Gains and Losses by Current, Never- and Ex-smokers of Cigarettes," Nicotine \& Tobacco Research 4, 295-303.

Perkins, Kenneth A. 1992. "Effects of Tobacco Smoking on Caloric Intake,” British Journal of Addiction 87, 193-205.

Seltzer, Carl C., Raymond Bosse, and Arthur J. Garvey. 1975. "Mail Survey Response by Smoking Status," American Journal of Epidemiology 100 (6), 453-457.

Smith, Patricia K., Barry Bogin, and David Bishai. 2005. “Are Time Preference and Body Mass Index Associated? Evidence from the National Longitudinal Survey of Youth,” Economics and Human Biology 3 (2), 259-270.

U.S. Bureau of Labor Statistics. 2006. "Linking American Time Use Survey and Current Population Survey Public Use Files,” mimeo. 
Table 1 Rotation Groups in the TUS-CPS and Their Interviews in the ATUS

\begin{tabular}{|c|c|c|c|c|c|}
\hline TUS-CPS & $\begin{array}{l}\text { Month in } \\
\text { sample }\end{array}$ & $\begin{array}{c}\text { Month of last } \\
\text { interview in CPS }\end{array}$ & $\begin{array}{c}\text { Months of interview } \\
\text { in ATUS }\end{array}$ & $\begin{array}{c}\text { Number of months } \\
\text { between TUS-CPS and } \\
\text { ATUS }\end{array}$ & Note \\
\hline \multirow[t]{8}{*}{ February 2003} & 8 & Feb 2003 & Apr-Jul 2003 & $2-5$ & No TUS interview \\
\hline & 7 & Mar 2003 & May-Aug 2003 & $3-6$ & \\
\hline & 6 & Apr 2003 & Jun-Sep 2003 & $4-7$ & \\
\hline & 5 & May 2003 & Jul-Oct 2003 & $5-8$ & \\
\hline & 4 & Feb 2004 & Apr-Jul 2004 & $14-17$ & No TUS interview \\
\hline & 3 & Mar 2004 & May-Aug 2004 & $15-18$ & \\
\hline & 2 & Apr 2004 & Jun-Sep 2004 & $16-19$ & \\
\hline & 1 & May 2004 & Jul-Oct 2004 & $17-20$ & \\
\hline \multirow[t]{8}{*}{ June 2003} & 8 & Jun 2003 & Aug-Nov 2003 & $2-5$ & \\
\hline & 7 & Jul 2003 & Sep-Dec 2003 & $3-6$ & \\
\hline & 6 & Aug 2003 & Oct 2003-Jan 2004 & $4-7$ & \\
\hline & 5 & Sep 2003 & Nov 2003-Feb 2004 & $5-8$ & \\
\hline & 4 & Jun 2004 & Aug-Nov 2004 & $14-17$ & \\
\hline & 3 & Jul 2004 & Sep-Dec 2004 & $15-18$ & \\
\hline & 2 & Aug 2004 & Oct 2004-Jan 2005 & $16-19$ & \\
\hline & 1 & Sep 2004 & Nov 2004-Feb 2005 & $17-20$ & \\
\hline \multirow[t]{8}{*}{ November 2003} & 8 & Nov 2003 & Jan-Apr 2004 & $2-5$ & \\
\hline & 7 & Dec 2003 & Feb-May 2004 & $3-6$ & \\
\hline & 6 & Jan 2004 & Mar-Jun 2004 & $4-7$ & \\
\hline & 5 & Feb 2004 & Apr-Jul 2004 & $5-8$ & \\
\hline & 4 & Nov 2004 & Jan-Apr 2005 & $14-17$ & \\
\hline & 3 & Dec 2004 & Feb-May 2005 & $15-18$ & \\
\hline & 2 & Jan 2005 & Mar-Jun 2005 & $16-19$ & \\
\hline & 1 & Feb 2005 & Apr-Jul 2005 & $17-20$ & \\
\hline
\end{tabular}


Table 2 Number of Matched Individuals between the AUTS and the TUS-CPS and the Final Sample Size

\begin{tabular}{lcccc}
\hline & 2003 & 2004 & 2005 & Total \\
\hline ATUS sample & 38,938 & 27,004 & 24,977 & 90,919 \\
$\begin{array}{l}\text { Matched to TUS-CPS by } \\
\text { identification variables }\end{array}$ & 15,892 & 16,115 & 5,010 & 37,017 \\
Sex, race, and age verified & 15,815 & 15,507 & 4,575 & 35,897 \\
ATUS complete interviews & 9,241 & 8,659 & 2,530 & 20,430
\end{tabular}

Notes: The sample from the TUS-CPS is limited to individuals over the age of 19 as of the TUS-CPS interview. 
Table 3 Proportion Responded in the ATUS by Smoking Status

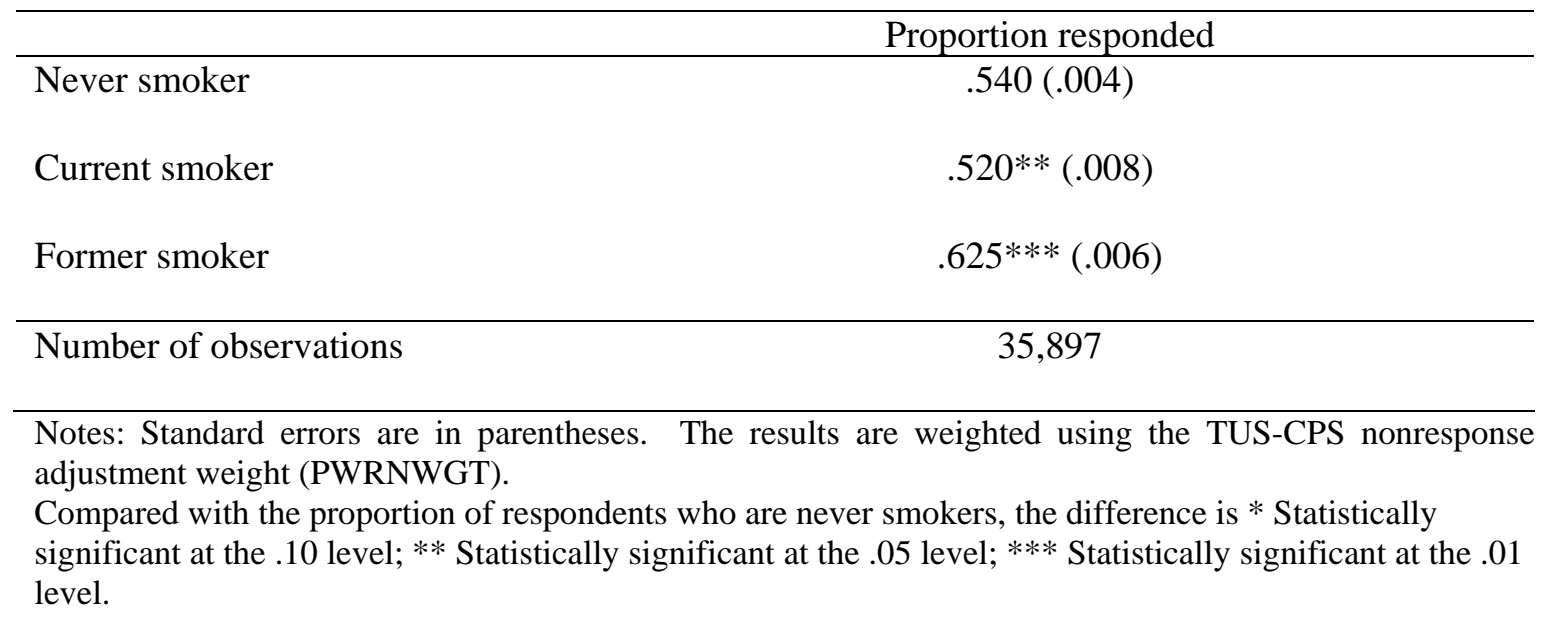


Table 4 Proportion in the ATUS by Smoking Status

\begin{tabular}{lcc}
\hline & Nonrespondent & Respondent \\
\hline Never smoker & $.647(.004)$ & $.614^{* * *}(.004)$ \\
Current smoker & $.191(.003)$ & $.168^{* * *}(.003)$ \\
Former smoker & $.162(.003)$ & $.219^{* * *}(.003)$ \\
\hline Number of observations & 15,467 & 20,430 \\
\hline
\end{tabular}

Notes: Standard erros are in parentheses. The results are weighted using the TUS-CPS nonresponse adjustment weight (PWRNWGT).

* Statistically significant at the .10 level; ** Statistically significant at the .05 level; *** Statistically significant at the .01 level. 
Table 5 Marginal Effects of Probit Estimation of ATUS Response

\begin{tabular}{|c|c|c|c|}
\hline & $\begin{array}{c}\text { (1) } \\
\text { Whole sample }\end{array}$ & $\begin{array}{l}\text { (2) } \\
\text { Male }\end{array}$ & $\begin{array}{c}\text { (3) } \\
\text { Female }\end{array}$ \\
\hline Female & $.056 * * *(.006)$ & & \\
\hline Age & $.013^{* * *}(.001)$ & $.011^{* * *}(.002)$ & $.014 * * *(.001)$ \\
\hline Age squared & $-.0001^{* * *}(.0000)$ & $-.0001 * * *(.0000)$ & $-.0001^{* * *}(.0000)$ \\
\hline Black & $-.086 * * *(.009)$ & $-.085 * * *(.015)$ & $-.087 * * *(.012)$ \\
\hline Hispanic & $-.018 *(.010)$ & $-.026 *(.015)$ & $-.011(.014)$ \\
\hline Other & $-.092 * * *(.015)$ & $-.051 * *(.023)$ & $-.126^{* * *}(.020)$ \\
\hline Married & $.031 * * *(.007)$ & $.011(.011)$ & $.046 * * *(.009)$ \\
\hline SMSA & $-.051 * * *(.008)$ & $-.046 * * *(.012)$ & $-.055 * * *(.011)$ \\
\hline High school graduate & $.031 * * *(.010)$ & $.064 * * *(.015)$ & $.004(.013)$ \\
\hline Some college & $.087 * * *(.010)$ & $.108 * * *(.015)$ & $.070 * * *(.013)$ \\
\hline College or higher & $.158 * * *(.010)$ & $.181 * * *(.016)$ & $.139 * * *(.014)$ \\
\hline Employed & $-.005(.008)$ & $-.012(.013)$ & $.003(.009)$ \\
\hline Number of children & $.003(.003)$ & $.009 *(.005)$ & $.0001(.004)$ \\
\hline Family income missing & $-.092 * * *(.011)$ & $-.070 * * *(.018)$ & $-.104 * * *(.014)$ \\
\hline Family income $\$ 20-39,999$ & $.020 * *(.010)$ & $.043 * * *(.016)$ & $.007(.012)$ \\
\hline Family income $\$ 40-74,999$ & $.026 * *(.010)$ & $.048 * * *(.017)$ & $.012(.014)$ \\
\hline Family income $\$ 75,000$ or more & $.030 * *(.012)$ & $.046 * *(.018)$ & $.019(.016)$ \\
\hline No telephone in household & $-.103 * * *(.016)$ & $-.124 * * *(.024)$ & $-.080 * * *(.023)$ \\
\hline Renter & $-.082 * * *(.008)$ & $-.088 * * *(.012)$ & $-.077 * * *(.010)$ \\
\hline June 2003 TUS-CPS & $.017 * *(.007)$ & $.016(.011)$ & $.018 * *(.009)$ \\
\hline November 2003 TUS-CPS & $.010(.008)$ & $.001(.011)$ & $.016(.010)$ \\
\hline Midwest & $.036 * * *(.009)$ & $.019(.014)$ & $.051 * * *(.012)$ \\
\hline South & $-.014 *(.008)$ & $-.032 * *(.013)$ & $.002(.011)$ \\
\hline West & $.009(.010)$ & $.005(.014)$ & $.012(.013)$ \\
\hline Current smoker & $.011(.008)$ & $.003(.012)$ & $.023 * *(.011)$ \\
\hline Former smoker & $.052 * * *(.008)$ & $.059 * * *(.012)$ & $.044 * * *(.011)$ \\
\hline Proportion responded & .553 & .530 & .571 \\
\hline Pseudo R-square & .0529 & .0558 & .0508 \\
\hline Number of observations & 35,897 & 15,833 & 20,064 \\
\hline
\end{tabular}

Notes: Standard errors are in parentheses. The results are weighted using the TUS-CPS nonresponse adjustment weight (PWRNWGT).

* Statistically significant at the .10 level; ** Statistically significant at the .05 level; *** Statistically significant at the .01 level. 
Table 6 Proportion of Respondents with Non-zero Smoking Time in the ATUS by Smoking Status from the TUS-CPS

\begin{tabular}{lc}
\hline & Proportion \\
\hline Never smoker & $.0021(.0006)$ \\
Current smoker & $.0975^{* * *}(.0073)$ \\
Former smoker & $.0057^{* *}(.0016)$ \\
\hline Number of observations & 20,430 \\
\hline $\begin{array}{l}\text { Notes: Standard errors are in parentheses. The results are weighted using the ATUS final weight. } \\
\text { Compared with the proportion of respondents who are never smokers, the difference is * Statistically } \\
\text { significant at the .10 level; ** Statistically significant at the .05 level; *** Statistically significant at the .01 } \\
\text { level. }\end{array}$
\end{tabular}


Table 7 Average Minutes Spent per Day on Activities by Sex and Smoking Status

\begin{tabular}{|c|c|c|c|c|c|c|}
\hline \multirow[b]{2}{*}{$\begin{array}{l}\text { Dependent } \\
\text { variables }\end{array}$} & \multicolumn{3}{|c|}{ Men } & \multicolumn{3}{|c|}{ Women } \\
\hline & $\begin{array}{c}\text { Never } \\
\text { smoker }\end{array}$ & $\begin{array}{l}\text { Current } \\
\text { smoker }\end{array}$ & $\begin{array}{l}\text { Former } \\
\text { smoker }\end{array}$ & $\begin{array}{c}\text { Never } \\
\text { smoker }\end{array}$ & $\begin{array}{l}\text { Current } \\
\text { smoker }\end{array}$ & $\begin{array}{l}\text { Former } \\
\text { smoker }\end{array}$ \\
\hline $\begin{array}{l}\text { Watching } \\
\text { television }\end{array}$ & $\begin{array}{l}148.89 \\
(2.81)\end{array}$ & $\begin{array}{c}199.71^{* * *} \\
(6.18)\end{array}$ & $\begin{array}{c}182.23^{* * *} \\
(4.32)\end{array}$ & $\begin{array}{l}138.06 \\
(2.13)\end{array}$ & $\begin{array}{c}163.37^{* * *} \\
(4.42)\end{array}$ & $\begin{array}{c}154.15^{* * *} \\
(3.87)\end{array}$ \\
\hline $\begin{array}{l}\text { Eating and } \\
\text { drinking }\end{array}$ & $\begin{array}{l}69.37 \\
(.90)\end{array}$ & $\begin{array}{l}70.17 \\
(2.13)\end{array}$ & $\begin{array}{c}79.30 * * * \\
(1.30)\end{array}$ & $\begin{array}{l}66.74 \\
(.66)\end{array}$ & $\begin{array}{c}61.00^{* * *} \\
(1.46)\end{array}$ & $\begin{array}{l}68.26 \\
(1.21)\end{array}$ \\
\hline Education & $\begin{array}{l}12.04 \\
(1.70)\end{array}$ & $\begin{array}{c}5.59 * * \\
(1.89)\end{array}$ & $\begin{array}{c}1.74 * * * \\
(.39)\end{array}$ & $\begin{array}{l}13.61 \\
(1.51)\end{array}$ & $\begin{array}{l}11.13 \\
(1.83)\end{array}$ & $\begin{array}{c}6.70 * * * \\
(1.02)\end{array}$ \\
\hline Sports & $\begin{array}{l}20.58 \\
(1.06)\end{array}$ & $\begin{array}{l}16.70 \\
(2.18)\end{array}$ & $\begin{array}{l}22.13 \\
(1.94)\end{array}$ & $\begin{array}{l}11.70 \\
(.53)\end{array}$ & $\begin{array}{c}6.71^{* * *} \\
(.78)\end{array}$ & $\begin{array}{l}13.10 \\
(1.02)\end{array}$ \\
\hline Working & $\begin{array}{l}287.90 \\
(5.30)\end{array}$ & $\begin{array}{c}255.31 * * * \\
(8.97)\end{array}$ & $\begin{array}{c}213.75 * * * \\
\quad(7.28)\end{array}$ & $\begin{array}{l}167.03 \\
(3.69)\end{array}$ & $\begin{array}{l}174.44 \\
(7.60)\end{array}$ & $\begin{array}{l}155.15 \\
(6.38)\end{array}$ \\
\hline $\begin{array}{l}\text { Number of } \\
\text { observations }\end{array}$ & 4,680 & 1,652 & 2,355 & 7,640 & 1,813 & 2,290 \\
\hline
\end{tabular}


Table 8 Descriptive Statistics by Sex and Smoking Status

\begin{tabular}{|c|c|c|c|c|c|c|}
\hline & $\begin{array}{l}\text { Never } \\
\text { smoker }\end{array}$ & $\begin{array}{c}\text { Men } \\
\text { Current } \\
\text { smoker }\end{array}$ & $\begin{array}{l}\text { Former } \\
\text { smoker }\end{array}$ & $\begin{array}{l}\text { Never } \\
\text { smoker }\end{array}$ & $\begin{array}{l}\text { Women } \\
\text { Current } \\
\text { smoker }\end{array}$ & $\begin{array}{l}\text { Former } \\
\text { smoker }\end{array}$ \\
\hline Age & $\begin{array}{l}42.765 \\
(.298)\end{array}$ & $\begin{array}{l}43.117 \\
(.486)\end{array}$ & $\begin{array}{c}55.380 * * * \\
(.411)\end{array}$ & $\begin{array}{l}47.058 \\
(.270)\end{array}$ & $\begin{array}{c}43.991 * * * \\
(.508)\end{array}$ & $\begin{array}{c}53.117 * * * \\
(.405)\end{array}$ \\
\hline White & $\begin{array}{l}.698 \\
(.009)\end{array}$ & $\begin{array}{c}.767 * * * \\
(.013)\end{array}$ & $\begin{array}{c}.846^{* * * *} \\
(.010)\end{array}$ & $\begin{array}{l}.706 \\
(.007)\end{array}$ & $\begin{array}{c}.787 * * * \\
(.013)\end{array}$ & $\begin{array}{c}.851^{* * *} \\
(.010)\end{array}$ \\
\hline Black & $\begin{array}{l}.100 \\
(.006)\end{array}$ & $\begin{array}{l}.096 \\
(.009)\end{array}$ & $\begin{array}{c}.067 * * * \\
(.007)\end{array}$ & $\begin{array}{l}.116 \\
(.005)\end{array}$ & $\begin{array}{c}.121 \\
(.010)\end{array}$ & $\begin{array}{c}.069 * * * \\
(.007)\end{array}$ \\
\hline Hispanic & $\begin{array}{l}.153 \\
(.008)\end{array}$ & $\begin{array}{c}.096 * * * \\
(.009)\end{array}$ & $\begin{array}{c}.055^{* * *} \\
(.006)\end{array}$ & $\begin{array}{l}.136 \\
(.005)\end{array}$ & $\begin{array}{c}.065 * * * \\
(.008)\end{array}$ & $\begin{array}{c}.054 * * * \\
(.006)\end{array}$ \\
\hline Other & $\begin{array}{c}.049 \\
(.004)\end{array}$ & $\begin{array}{l}.041 \\
(.007)\end{array}$ & $\begin{array}{c}.032 * * * \\
(.003)\end{array}$ & $\begin{array}{c}.042 \\
(.003)\end{array}$ & $\begin{array}{c}.027^{* * *} \\
(.004)\end{array}$ & $\begin{array}{l}.026 * * \\
(.005)\end{array}$ \\
\hline $\begin{array}{l}\text { Less than high } \\
\text { school }\end{array}$ & $\begin{array}{l}.105 \\
(.006)\end{array}$ & $\begin{array}{c}.161 * * * \\
(.013)\end{array}$ & $\begin{array}{c}.137^{* * *} \\
(.009)\end{array}$ & $\begin{array}{l}.134 \\
(.005)\end{array}$ & $\begin{array}{l}.140 \\
(.011)\end{array}$ & $\begin{array}{c}.106 * * * \\
(.008)\end{array}$ \\
\hline High school & $\begin{array}{l}.271 \\
(.009)\end{array}$ & $\begin{array}{c}.446 * * * \\
(.016)\end{array}$ & $\begin{array}{l}.322 * * * \\
(.012)\end{array}$ & $\begin{array}{l}.295 \\
(.007)\end{array}$ & $\begin{array}{c}.442^{* * *} \\
(.016)\end{array}$ & $\begin{array}{l}.322^{*} \\
(.013)\end{array}$ \\
\hline Some college & $\begin{array}{c}.251 \\
(.009)\end{array}$ & $\begin{array}{c}.258 \\
(.013)\end{array}$ & $\begin{array}{c}.255 \\
(.011)\end{array}$ & $\begin{array}{l}.262 \\
(.007)\end{array}$ & $\begin{array}{l}.297^{* *} \\
(.014)\end{array}$ & $\begin{array}{c}.302^{* * *} \\
(.012)\end{array}$ \\
\hline College or higher & $\begin{array}{l}.372 \\
(.009)\end{array}$ & $\begin{array}{c}.136^{* * *} \\
(.010)\end{array}$ & $\begin{array}{c}.286^{* * *} \\
(.011)\end{array}$ & $\begin{array}{c}.308 \\
(.007)\end{array}$ & $\begin{array}{c}.122 * * * \\
(.009)\end{array}$ & $\begin{array}{c}.270 * * * \\
(.011)\end{array}$ \\
\hline Employed & $\begin{array}{l}.803 \\
(.008)\end{array}$ & $\begin{array}{c}.741 * * * \\
(.014)\end{array}$ & $\begin{array}{c}.615^{* * *} \\
(.013)\end{array}$ & $\begin{array}{l}.590 \\
(.007)\end{array}$ & $\begin{array}{c}.612 \\
(.015)\end{array}$ & $\begin{array}{c}.574 \\
(.013)\end{array}$ \\
\hline Married & $\begin{array}{l}.659 \\
(.010)\end{array}$ & $\begin{array}{c}.534 * * * \\
(.016)\end{array}$ & $\begin{array}{c}.743^{* * *} \\
(.011)\end{array}$ & $\begin{array}{l}.604 \\
(.007)\end{array}$ & $\begin{array}{c}.500 * * * \\
(.016)\end{array}$ & $\begin{array}{l}.637 * * \\
(.012)\end{array}$ \\
\hline $\begin{array}{l}\text { Number of children } \\
\text { in the household }\end{array}$ & $\begin{array}{c}.834 \\
(.022)\end{array}$ & $\begin{array}{c}.612^{* * *} \\
(.030)\end{array}$ & $\begin{array}{c}.461 * * * \\
(.022)\end{array}$ & $\begin{array}{c}.781 \\
(.017)\end{array}$ & $\begin{array}{c}.680 * * * \\
(.029)\end{array}$ & $\begin{array}{c}.553^{* * *} \\
(.024)\end{array}$ \\
\hline $\begin{array}{l}\text { Number of } \\
\text { observations }\end{array}$ & 4,680 & 1,652 & 2,355 & 7,640 & 1,813 & 2,290 \\
\hline
\end{tabular}


Table 9 OLS Estimations of Minutes Spent on Activities per Day, Men

\begin{tabular}{|c|c|c|c|c|c|}
\hline & $\begin{array}{c}\text { (1) } \\
\text { Watching } \\
\text { television }\end{array}$ & $\begin{array}{c}(2) \\
\text { Eating and } \\
\text { drinking }\end{array}$ & $\begin{array}{c}\text { (3) } \\
\text { Education }\end{array}$ & $\begin{array}{l}(4) \\
\text { Sports }\end{array}$ & $\begin{array}{c}\text { (5) } \\
\text { Working }\end{array}$ \\
\hline Current smoker & $\begin{array}{c}26.40 * * * \\
(6.16)\end{array}$ & $\begin{array}{l}4.08^{*} \\
(2.28)\end{array}$ & $\begin{array}{c}-5.85 * * * \\
(2.84)\end{array}$ & $\begin{array}{l}-1.81 \\
(2.46)\end{array}$ & $\begin{array}{l}-11.57 \\
(8.05)\end{array}$ \\
\hline Former smoker & $\begin{array}{c}1.69 \\
(4.86)\end{array}$ & $\begin{array}{c}4.41 * * * \\
(1.63)\end{array}$ & $\begin{array}{c}-4.21 * * * \\
(1.14)\end{array}$ & $\begin{array}{l}4.26^{*} \\
(2.49)\end{array}$ & $\begin{array}{c}-13.56^{* *} \\
(6.90)\end{array}$ \\
\hline Age & $\begin{array}{l}1.82^{*} \\
(.95)\end{array}$ & $\begin{array}{l}-.15 \\
(.30)\end{array}$ & $\begin{array}{c}-2.36 * * * \\
(.49)\end{array}$ & $\begin{array}{c}-.76^{* *} \\
(.37)\end{array}$ & $\begin{array}{c}5.12^{* * *} \\
(1.16)\end{array}$ \\
\hline Age squared & $\begin{array}{l}-.01 \\
(.01)\end{array}$ & $\begin{array}{c}.006^{* *} \\
(.003)\end{array}$ & $\begin{array}{c}.02 * * * \\
(.00)\end{array}$ & $\begin{array}{l}.005 \\
(.003)\end{array}$ & $\begin{array}{c}-.06^{* * *} \\
(.01)\end{array}$ \\
\hline Black & $\begin{array}{c}32.21^{* *} \\
(9.16)\end{array}$ & $\begin{array}{c}-21.01^{* * *} \\
(2.18)\end{array}$ & $\begin{array}{c}1.50 \\
(3.16)\end{array}$ & $\begin{array}{l}-4.09 \\
(2.82)\end{array}$ & $\begin{array}{c}-26.60 * * * \\
(10.32)\end{array}$ \\
\hline Hispanic & $\begin{array}{c}.94 \\
(.7 .37)\end{array}$ & $\begin{array}{c}-.87 \\
(2.23)\end{array}$ & $\begin{array}{c}-.07 \\
(3.21)\end{array}$ & $\begin{array}{c}.46 \\
(3.55)\end{array}$ & $\begin{array}{c}-7.03 \\
(11.29)\end{array}$ \\
\hline Other & $\begin{array}{c}9.15 \\
(10.22)\end{array}$ & $\begin{array}{c}3.68 \\
(3.24)\end{array}$ & $\begin{array}{c}11.11 \\
(12.38)\end{array}$ & $\begin{array}{c}3.11 \\
(4.54)\end{array}$ & $\begin{array}{l}-16.25 \\
(16.76)\end{array}$ \\
\hline High school & $\begin{array}{l}-8.67 \\
(8.66)\end{array}$ & $\begin{array}{c}3.14 \\
(2.47)\end{array}$ & $\begin{array}{c}1.26 \\
(2.19)\end{array}$ & $\begin{array}{l}-2.16 \\
(3.51)\end{array}$ & $\begin{array}{l}-2.33 \\
(9.76)\end{array}$ \\
\hline Some college & $\begin{array}{c}-23.95^{* * *} \\
(8.56)\end{array}$ & $\begin{array}{l}4.42 * \\
(2.50)\end{array}$ & $\begin{array}{c}15.40^{* * *} \\
(3.88)\end{array}$ & $\begin{array}{l}-3.22 \\
(3.52)\end{array}$ & $\begin{array}{c}-5.63 \\
(10.58)\end{array}$ \\
\hline College or higher & $\begin{array}{c}-47.78^{* * * *} \\
(8.60)\end{array}$ & $\begin{array}{c}11.29 * * * \\
(2.62)\end{array}$ & $\begin{array}{c}10.12 * * * \\
(2.95)\end{array}$ & $\begin{array}{c}2.86 \\
(3.71)\end{array}$ & $\begin{array}{c}-2.47 \\
(10.76)\end{array}$ \\
\hline Employed & $\begin{array}{c}-90.34^{* * *} \\
(7.47)\end{array}$ & $\begin{array}{l}-1.28 \\
(1.96)\end{array}$ & $\begin{array}{c}-14.61^{* * *} \\
(3.97)\end{array}$ & $\begin{array}{c}-10.22 * * * \\
(2.56)\end{array}$ & $\begin{array}{c}330.16^{* * *} \\
(6.91)\end{array}$ \\
\hline Married & $\begin{array}{l}-4.96 \\
(5.09)\end{array}$ & $\begin{array}{c}1.65 \\
(1.91)\end{array}$ & $\begin{array}{c}-3.69 * * \\
(2.09)\end{array}$ & $\begin{array}{l}-1.70 \\
(2.10)\end{array}$ & $\begin{array}{l}-6.14 \\
(6.49)\end{array}$ \\
\hline $\begin{array}{l}\text { Number of } \\
\text { children }\end{array}$ & $\begin{array}{c}-9.44 * * * \\
(2.00)\end{array}$ & $\begin{array}{l}-.53 \\
(.67)\end{array}$ & $\begin{array}{c}-2.31^{* *} \\
(1.03)\end{array}$ & $\begin{array}{c}-.38 \\
(1.14)\end{array}$ & $\begin{array}{l}-1.52 \\
(3.17)\end{array}$ \\
\hline Constant & $\begin{array}{c}.48 \\
(27.21)\end{array}$ & $\begin{array}{c}58.94 * * * \\
(8.79)\end{array}$ & $\begin{array}{c}95.12 * * * \\
(17.93)\end{array}$ & $\begin{array}{c}38.24 * * * \\
(11.18)\end{array}$ & $\begin{array}{l}-11.71 \\
(36.07)\end{array}$ \\
\hline $\begin{array}{l}\text { R-squared } \\
\text { Number of } \\
\text { observations }\end{array}$ & .1933 & .0622 & $\begin{array}{l}.0728 \\
8,687\end{array}$ & .0229 & .4709 \\
\hline $\begin{array}{l}\text { Notes: Standard er } \\
\text { The regressions } \\
\text { dummies, Saturday } \\
\text { * Statistically sign } \\
\text { significant at the .0 }\end{array}$ & at the 10 & ** Statisti & eighted $u$ & $\begin{array}{l}\text { ATUS fi } \\
\text { yariables: }\end{array}$ & $\begin{array}{l}\text { ight. } \\
\text { amily ince } \\
\text { stically }\end{array}$ \\
\hline
\end{tabular}


Table 10 OLS Estimations of Minutes Spent on Activities per Day, Women

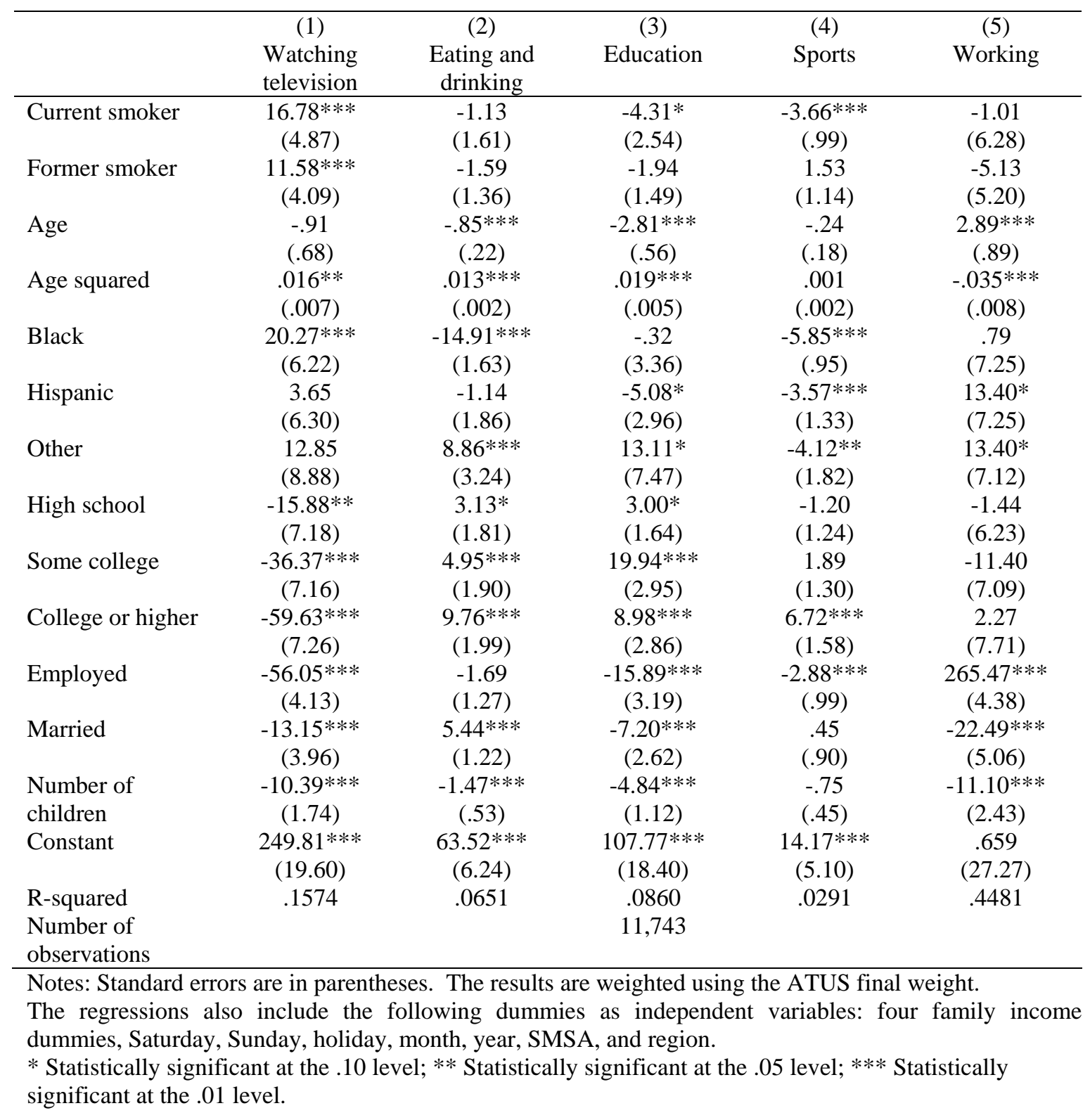


Table 11 Marginal Effects of Tobit Estimations of Minutes Spent on Activities per Day, Men

\begin{tabular}{|c|c|c|c|c|c|}
\hline & $\begin{array}{c}\text { (1) } \\
\text { Watching } \\
\text { television }\end{array}$ & $\begin{array}{c}\text { (2) } \\
\text { Eating and } \\
\text { drinking }\end{array}$ & $\begin{array}{c}\text { (3) } \\
\text { Education }\end{array}$ & $\begin{array}{l}\text { (4) } \\
\text { Sports }\end{array}$ & $\begin{array}{c}\text { (5) } \\
\text { Working }\end{array}$ \\
\hline Current smoker & $\begin{array}{c}24.96 * * * \\
(5.97)\end{array}$ & $\begin{array}{l}3.63^{*} \\
(2.15)\end{array}$ & $\begin{array}{c}-1.88 * * * \\
(.51)\end{array}$ & $\begin{array}{c}-5.00 * * * \\
(1.94)\end{array}$ & $\begin{array}{l}-8.60 \\
(7.19)\end{array}$ \\
\hline Former smoker & $\begin{array}{c}2.70 \\
(4.66)\end{array}$ & $\begin{array}{c}4.08 * * * \\
(1.54)\end{array}$ & $\begin{array}{c}-1.14^{* *} \\
(.56)\end{array}$ & $\begin{array}{c}1.19 \\
(1.79)\end{array}$ & $\begin{array}{c}-14.04^{* *} \\
(6.46)\end{array}$ \\
\hline Age & $\begin{array}{l}1.65^{*} \\
(.89)\end{array}$ & $\begin{array}{l}-.14 \\
(.28)\end{array}$ & $\begin{array}{c}-.48^{* * *} \\
(.11)\end{array}$ & $\begin{array}{c}-.68 * * \\
(.30)\end{array}$ & $\begin{array}{c}7.11^{* * * *} \\
(1.37)\end{array}$ \\
\hline Age squared & $\begin{array}{l}-.010 \\
(.009)\end{array}$ & $\begin{array}{l}.005^{*} \\
(.003)\end{array}$ & $\begin{array}{l}.003^{* * *} \\
(.001)\end{array}$ & $\begin{array}{l}.005^{*} \\
(.003)\end{array}$ & $\begin{array}{c}-.084 * * * \\
(.015)\end{array}$ \\
\hline Black & $\begin{array}{c}26.92 * * * \\
(8.93)\end{array}$ & $\begin{array}{c}-19.87 * * * \\
(1.97)\end{array}$ & $\begin{array}{c}.97 \\
(1.06)\end{array}$ & $\begin{array}{l}-1.86 \\
(2.68)\end{array}$ & $\begin{array}{c}-24.86^{* *} \\
(10.55)\end{array}$ \\
\hline Hispanic & $\begin{array}{c}4.32 \\
(7.17)\end{array}$ & $\begin{array}{c}-.65 \\
(2.13)\end{array}$ & $\begin{array}{l}-.12 \\
(.81)\end{array}$ & $\begin{array}{c}.41 \\
(2.82)\end{array}$ & $\begin{array}{l}-4.54 \\
(9.85)\end{array}$ \\
\hline Other & $\begin{array}{c}6.90 \\
(10.05)\end{array}$ & $\begin{array}{l}3.58 \\
(3.09)\end{array}$ & $\begin{array}{c}.16 \\
(1.55)\end{array}$ & $\begin{array}{l}2.75 \\
(3.62)\end{array}$ & $\begin{array}{l}-16.33 \\
(14.19)\end{array}$ \\
\hline High school & $\begin{array}{l}-2.28 \\
(8.10)\end{array}$ & $\begin{array}{l}3.46 \\
(2.37)\end{array}$ & $\begin{array}{c}.25 \\
(1.24)\end{array}$ & $\begin{array}{l}-2.39 \\
(3.03)\end{array}$ & $\begin{array}{c}1.10 \\
(10.97)\end{array}$ \\
\hline Some college & $\begin{array}{c}-15.59^{*} \\
(8.00)\end{array}$ & $\begin{array}{l}4.71 * \\
(2.42)\end{array}$ & $\begin{array}{c}7.17 * * * \\
(2.78)\end{array}$ & $\begin{array}{c}-.97 \\
(3.10)\end{array}$ & $\begin{array}{c}1.99 \\
(11.46)\end{array}$ \\
\hline College or higher & $\begin{array}{c}-39.59 * * * \\
(7.92)\end{array}$ & $\begin{array}{c}11.25^{* * *} \\
(2.53)\end{array}$ & $\begin{array}{l}6.31 * * \\
(2.49)\end{array}$ & $\begin{array}{c}9.15^{* * * *} \\
(3.56)\end{array}$ & $\begin{array}{c}5.66 \\
(11.45)\end{array}$ \\
\hline Employed & $\begin{array}{c}-82.59 * * * \\
(7.27)\end{array}$ & $\begin{array}{c}-.97 \\
(1.86)\end{array}$ & $\begin{array}{c}-4.67 * * * \\
(1.36)\end{array}$ & $\begin{array}{c}-9.88 * * * \\
(2.45)\end{array}$ & $\begin{array}{c}303.65^{* * * *} \\
(5.10)\end{array}$ \\
\hline Married & $\begin{array}{l}-1.55 \\
(4.88)\end{array}$ & $\begin{array}{l}1.90 \\
(1.79)\end{array}$ & $\begin{array}{c}-1.67^{* *} \\
(.83)\end{array}$ & $\begin{array}{l}-1.67 \\
(1.73)\end{array}$ & $\begin{array}{c}3.25 \\
(6.31)\end{array}$ \\
\hline $\begin{array}{l}\text { Number of } \\
\text { children }\end{array}$ & $\begin{array}{c}-9.62 * * * \\
(2.04)\end{array}$ & $\begin{array}{l}-.50 \\
(.64)\end{array}$ & $\begin{array}{c}-.40 \\
(.033)\end{array}$ & $\begin{array}{l}-1.05 \\
(.84)\end{array}$ & $\begin{array}{l}-3.85 \\
(2.62)\end{array}$ \\
\hline $\begin{array}{l}\text { Log } \\
\text { pseudolikelihood }\end{array}$ & $-2.606 e+11$ & $-2.453 e+11$ & $-1.502 e+10$ & $-7.025 e+10$ & $-1.904 \mathrm{e}+11$ \\
\hline $\begin{array}{l}\text { Proportion with } \\
\text { zero time use } \\
\text { Number of } \\
\text { observations }\end{array}$ & .1889 & .0509 & $\begin{array}{l}.9742 \\
8,687\end{array}$ & .8177 & .5390 \\
\hline
\end{tabular}

Notes: Standard errors are in parentheses. The results are weighted using the ATUS final weight.

The regressions also include the following dummies as independent variables: four family income dummies, Saturday, Sunday, holiday, month, year, SMSA, and region.

* Statistically significant at the .10 level; ** Statistically significant at the .05 level; *** Statistically significant at the .01 level. 
Table 12 Marginal Effects of Tobit Estimations of Minutes Spent on Activities per Day, Women

\begin{tabular}{|c|c|c|c|c|c|}
\hline & $\begin{array}{c}\text { (1) } \\
\text { Watching } \\
\text { television }\end{array}$ & $\begin{array}{c}\text { (2) } \\
\text { Eating and } \\
\text { drinking }\end{array}$ & $\begin{array}{c}\text { (3) } \\
\text { Education }\end{array}$ & $\begin{array}{l}\text { (4) } \\
\text { Sports }\end{array}$ & $\begin{array}{c}\text { (5) } \\
\text { Working }\end{array}$ \\
\hline Current smoker & $\begin{array}{c}16.78^{* * *} \\
(4.66)\end{array}$ & $\begin{array}{c}.97 \\
(1.53)\end{array}$ & $\begin{array}{l}-1.31 \\
(.96)\end{array}$ & $\begin{array}{c}-4.54 * * * \\
(.85)\end{array}$ & $\begin{array}{c}.52 \\
(3.20)\end{array}$ \\
\hline Former smoker & $\begin{array}{c}11.95^{* * *} \\
(3.92)\end{array}$ & $\begin{array}{l}-1.45 \\
(1.28)\end{array}$ & $\begin{array}{l}.03 \\
(.97)\end{array}$ & $\begin{array}{c}.78 \\
(.85)\end{array}$ & $\begin{array}{l}-2.82 \\
(2.70)\end{array}$ \\
\hline Age & $\begin{array}{c}-1.12^{*} \\
(.63)\end{array}$ & $\begin{array}{c}-.80^{* * * *} \\
(.21)\end{array}$ & $\begin{array}{c}-.72 * * * \\
(.15)\end{array}$ & $\begin{array}{l}-.16 \\
(.14)\end{array}$ & $\begin{array}{c}3.11^{* * * *} \\
(58)\end{array}$ \\
\hline Age squared & $\begin{array}{c}.017 * * * \\
(.006)\end{array}$ & $\begin{array}{c}.012 * * * \\
(.002)\end{array}$ & $\begin{array}{c}.004^{* * * *} \\
(.002)\end{array}$ & $\begin{array}{l}.001 \\
(.001)\end{array}$ & $\begin{array}{c}-.038 * * * \\
(.006)\end{array}$ \\
\hline Black & $\begin{array}{c}17.34^{* * *} \\
(5.96)\end{array}$ & $\begin{array}{c}-14.16^{* * *} \\
(1.51)\end{array}$ & $\begin{array}{c}1.12 \\
(1.39)\end{array}$ & $\begin{array}{c}-5.23 * * * \\
(.86)\end{array}$ & $\begin{array}{c}-.95 \\
(3.87)\end{array}$ \\
\hline Hispanic & $\begin{array}{c}5.20 \\
(5.97)\end{array}$ & $\begin{array}{c}-.86 \\
(1.78)\end{array}$ & $\begin{array}{l}-1.13 \\
(1.23)\end{array}$ & $\begin{array}{c}-3.31 * * * \\
(.98)\end{array}$ & $\begin{array}{l}7.73^{*} \\
(4.28)\end{array}$ \\
\hline Other & $\begin{array}{l}10.20 \\
(8.85)\end{array}$ & $\begin{array}{c}8.22 * * * \\
(3.17)\end{array}$ & $\begin{array}{l}5.80^{*} \\
(3.12)\end{array}$ & $\begin{array}{l}-2.52^{*} \\
(1.43)\end{array}$ & $\begin{array}{l}-3.04 \\
(5.35)\end{array}$ \\
\hline High school & $\begin{array}{c}-11.15^{*} \\
(6.26)\end{array}$ & $\begin{array}{l}2.99 * \\
(1.74)\end{array}$ & $\begin{array}{c}3.96 * * \\
(1.85)\end{array}$ & $\begin{array}{c}-.73 \\
(1.36)\end{array}$ & $\begin{array}{c}3.40 \\
(5.43)\end{array}$ \\
\hline Some college & $\begin{array}{c}-30.08^{* * * *} \\
(6.17)\end{array}$ & $\begin{array}{l}4.68 * * \\
(1.85)\end{array}$ & $\begin{array}{c}16.89 * * * \\
(3.50)\end{array}$ & $\begin{array}{l}2.76^{*} \\
(1.54)\end{array}$ & $\begin{array}{l}-1.73 \\
(5.33)\end{array}$ \\
\hline College or higher & $\begin{array}{c}-51.07^{* * * *} \\
(6.13)\end{array}$ & $\begin{array}{c}9.48^{* * * *} \\
(1.94)\end{array}$ & $\begin{array}{c}12.75^{* * *} \\
(3.22)\end{array}$ & $\begin{array}{c}7.32 * * * \\
(1.87)\end{array}$ & $\begin{array}{c}4.80 \\
(5.76)\end{array}$ \\
\hline Employed & $\begin{array}{c}-51.11 * * * \\
(3.96)\end{array}$ & $\begin{array}{l}-1.55 \\
(1.22)\end{array}$ & $\begin{array}{c}-5.63 * * * \\
(1.11)\end{array}$ & $\begin{array}{c}-2.32 * * * \\
(.82)\end{array}$ & $\begin{array}{c}222.74 * * * \\
(4.69)\end{array}$ \\
\hline Married & $\begin{array}{c}-9.28^{* *} \\
(3.76)\end{array}$ & $\begin{array}{c}5.49 * * * \\
(1.17)\end{array}$ & $\begin{array}{c}-2.57 * * * \\
(.99)\end{array}$ & $\begin{array}{l}.28 \\
(.79)\end{array}$ & $\begin{array}{c}-10.73^{* * * *} \\
(3.03)\end{array}$ \\
\hline $\begin{array}{l}\text { Number of } \\
\text { children }\end{array}$ & $\begin{array}{c}-10.22 * * * \\
(1.73)\end{array}$ & $\begin{array}{c}-1.35 * * * \\
(.51)\end{array}$ & $\begin{array}{c}-1.11^{* * * *} \\
(.38)\end{array}$ & $\begin{array}{c}-1.12 * * * \\
(.37)\end{array}$ & $\begin{array}{c}-6.12 * * * \\
(1.29)\end{array}$ \\
\hline $\begin{array}{l}\text { Log } \\
\text { pseudolikelihood }\end{array}$ & $-2.851 \mathrm{e}+11$ & $-2.719 e+11$ & $-2.674 \mathrm{e}+10$ & $-6.634 \mathrm{e}+10$ & $-1.565 \mathrm{e}+11$ \\
\hline $\begin{array}{l}\text { Proportion with } \\
\text { zero time use }\end{array}$ & .2215 & .0496 & .9561 & .8507 & .6790 \\
\hline $\begin{array}{l}\text { Number of } \\
\text { observations }\end{array}$ & & & 11,743 & & \\
\hline
\end{tabular}




\section{Appendix}

\section{Table A1 Time-use Variables and the ATUS Classification Codes}

\begin{tabular}{lll}
\hline Time-use variable & Activities & $\begin{array}{l}\text { Classification } \\
\text { codes }\end{array}$ \\
\hline Working & Working & 0501xx \\
Education & $\begin{array}{l}\text { Taking class, extracurricular school activities (except sports), } \\
\text { research/homework, registration/administrative activities }\end{array}$ & 06xxxx \\
Eating and drinking & Eating and drinking & $11 \mathrm{xxxx}$ \\
Smoking & Tobacco and drug use & 120302 \\
Watching television & Watching television and movies (not religious) & 120303 \\
Sports & Participating in sports, exercise, or recreation & 1301xx \\
\hline
\end{tabular}

Notes: In the six-digit classification codes, the first two digits represent the major activity category, the next two digits the 2nd-tier level of detail, and the final two digits the 3rd level of activity. 